\title{
Prp2-mediated protein rearrangements at the catalytic core of the spliceosome as revealed by dcFCCS
}

\author{
THOMAS OHRT, ${ }^{1,3}$ MIRA PRIOR, ${ }^{2,3}$ JULIA DANNENBERG, ${ }^{1}$ PETER ODENWÄLDER, ${ }^{1}$ OLEXANDR DYBKOV, ${ }^{1}$ \\ NICOLAS RASCHE, ${ }^{1}$ JANA SCHMITZOVÁ, ${ }^{1}$ INGO GREGOR, ${ }^{2}$ PATRIZIA FABRIZIO, ${ }^{1}$ JÖRG ENDERLEIN, ${ }^{2,4}$ \\ and REINHARD LÜHRMANN ${ }^{1,4}$ \\ ${ }^{1}$ Max Planck Institute for Biophysical Chemistry, D-37077 Göttingen, Germany \\ ${ }^{2}$ III. Physikalisches Institut (Biophysik), University of Göttingen, D-37077 Göttingen, Germany
}

\begin{abstract}
The compositional and conformational changes during catalytic activation of the spliceosome promoted by the DEAH box ATPase Prp2 are only poorly understood. Here, we show by dual-color fluorescence cross-correlation spectroscopy (dcFCCS) that the binding affinity of several proteins is significantly changed during the Prp2-mediated transition of precatalytic $B^{\text {act }}$ spliceosomes to catalytically activated B* spliceosomes from Saccharomyces cerevisiae. During this step, several proteins, including the zinc-finger protein $\mathrm{Cwc24}$, are quantitatively displaced from the B* complex. Consistent with this, we show that Cwc24 is required for step 1 but not for catalysis per se. The U2-associated SF3a and SF3b proteins Prp11 and Cus1 remain bound to the $B^{*}$ spliceosome under near-physiological conditions, but their binding is reduced at high salt. Conversely, high-affinity binding sites are created for Yju2 and Cwc25 during catalytic activation, consistent with their requirement for step 1 catalysis. Our results suggest high cooperativity of multiple Prp2-mediated structural rearrangements at the spliceosome's catalytic core. Moreover, dcFCCS represents a powerful tool ideally suited to study quantitatively spliceosomal protein dynamics in equilibrium.
\end{abstract}

Keywords: Cwc24; dcFCCS; Prp2-mediated; spliceosome dynamics; U2 SF3a/b

\section{INTRODUCTION}

The removal of introns from nuclear pre-mRNAs proceeds by way of two phosphoester transfer reactions and is catalyzed by the spliceosome, a large ribonucleoprotein (RNP) complex comprising the snRNPs U1, U2, U4/U6, and U5 and, in yeast, about 90 proteins (Wahl et al. 2009; Will and Lührmann 2011). The spliceosome is a dynamic molecular machine: its conformation and composition change almost continuously during the spliceosomal assembly and reaction cycle, including the catalytic activation steps of the spliceosome. This is particularly the case for the proteins of the spliceosome.

Initially, the spliceosome assembles by recruitment of the snRNPs, leading to a multimegadalton ensemble (the " $\mathrm{B}$ complex") that, however, does not yet have an active site. Subsequent activation of the spliceosome (leading to the $\mathrm{B}^{\text {act }}$ complex) involves major rearrangement of the spliceosomal RNA-RNA interaction network. This rearrangement is

\footnotetext{
${ }^{3}$ These authors contributed equally to this work.

${ }^{4}$ Corresponding authors.

E-mail reinhard.luehrmann@mpi-bpc.mpg.de.

E-mail joerg.enderlein@physik3.gwdg.de.

Article published online ahead of print. Article and publication date are at http://www.rnajournal.org/cgi/doi/10.1261/rna.033316.112.
}

catalyzed by the combined action of the RNA helicases Prp28 and Brr2 in cooperation with the GTPase Snu114 and includes the displacement of the U1 and U4 snRNAs and the formation of new base pair interactions between the U6 and U2 snRNAs and the 5' splice site (SS) (Staley and Guthrie 1998). The resulting RNA structure plays a central role in catalyzing both steps of splicing (Nilsen 1998).

During the transition from complex $\mathrm{B}$ to $\mathrm{B}^{\text {act }}$, not only is the spliceosome's RNA network radically rearranged, but also its protein composition changes significantly, as shown by mass-spectrometric (MS) analysis of purified yeast spliceosomes that have been stalled at defined assembly stages by biochemical or genetic means (Fabrizio et al. 2009; Warkocki et al. 2009). These studies revealed that, during activation of the yeast spliceosome, $\sim 25$ proteins are displaced, including all of the $\mathrm{U} 1$ and $\mathrm{U} 4 / \mathrm{U} 6$ proteins, while at least 19 other proteins are stably recruited to the $\mathrm{B}^{\text {act }}$ complex. These include eight proteins of the core complex NTC ("NineTeen Complex") and 12 further proteins, which are hereinafter termed NTC-related proteins (Fig. 1; Chang et al. 2009; Fabrizio et al. 2009).

Despite the substantial restructuring that the spliceosome has undergone at this point, it does not yet have a functional active site. For catalytic activation of the spliceosome, the 


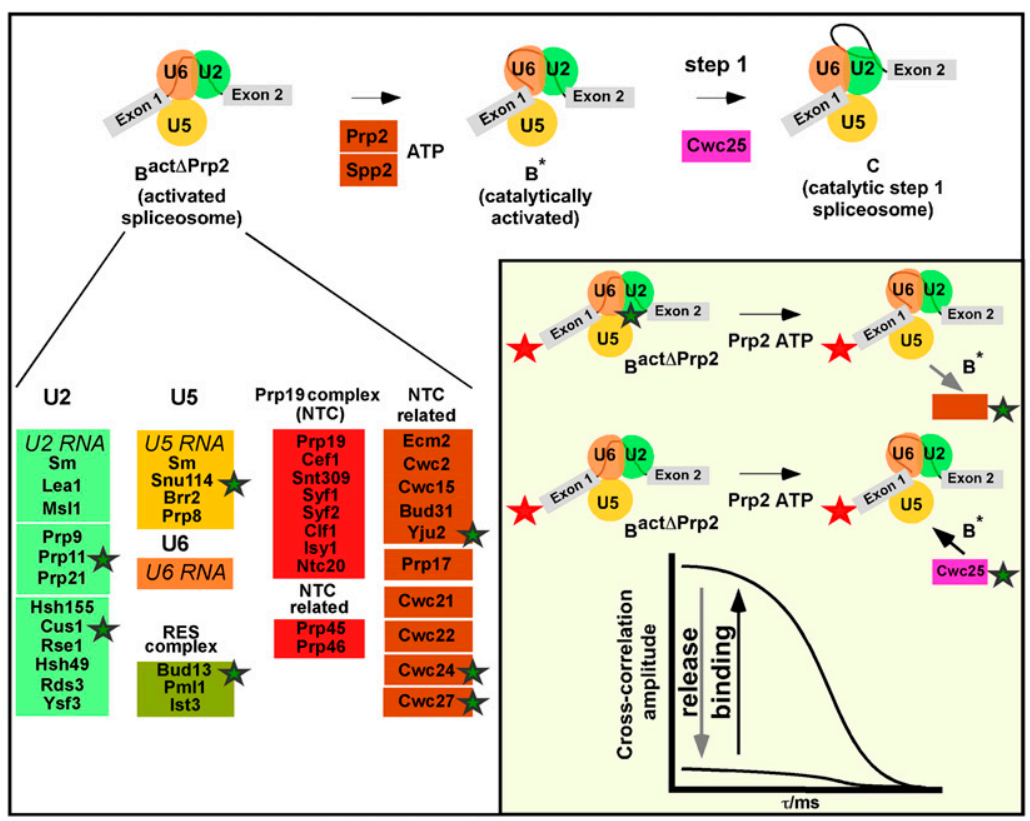

FIGURE 1. Experimental design and example of data. The Prp2-deficient spliceosomal complex $\mathrm{B}^{\text {act } \Delta \operatorname{Prp} 2}$ (stalled through its lack of Prp2) is catalytically activated by addition of Prp2 together with Spp2 and ATP. This leads to complex $B^{\star}$, which, on binding the step 1 factor Cwc25, catalyzes step 1 of splicing, generating complex C; for details, see Introduction. U2/5/6 snRNPs are shown as circles. The composition of the activated spliceosome is shown underneath; green stars indicate the spliceosomal proteins that were tagged with EGFP. (Inset) Release or recruitment of an EGFP-labeled protein (green star) from/to the spliceosome (carrying Atto647N, red star). The cross-correlation amplitude at short correlation time $\tau$ is proportional to the amount of doubly labeled spliceosomes.

DEAH box ATPase Prp2 binds together with a cofactor, Spp2, to the $\mathrm{B}^{\text {act }}$ complex. Prp2 requires Spp2 for its recruitment to the spliceosome and, consequently, for its function (Roy et al. 1995; Silverman et al. 2004). Upon ATP hydrolysis, Prp2 sets off a process in which the spliceosome is structurally remodeled, which leads to the $\mathrm{B}^{\star}$ complex. In cooperation with proteins needed for catalyzing step 1 ("step 1 factors"), such as Yju2 and Cwc25, the $\mathrm{B}^{\star}$ complex then catalyzes the first step of the splicing reaction (Chiu et al. 2009; Warkocki et al. 2009). At the same time, the spliceosomal C complex is formed and then, following a further structural rearrangement mediated by the DEAH box ATPase Prp16 and recruitment of the step 2 factors Slu7, Prp18, and Prp22 (Schwer and Gross 1998; James et al. 2002; Horowitz 2011), the second step of splicing is catalyzed.

How the RNP structure and composition of the spliceosome changes during the Prp2-mediated remodeling of $\mathrm{B}^{\text {act }}$ into the catalytically activated $\mathrm{B}^{\star}$ complex is only poorly understood, and nothing is known about the potential target structure(s) of Prp2. However, the Prp2-mediated remodeling of the spliceosome appears to be very substantial, as suggested by the accompanying change in the Svedberg value from $45 \mathrm{~S}\left(\mathrm{~B}^{\text {act }}\right)$ to $40 \mathrm{~S}\left(\mathrm{~B}^{*}\right)$ and by clear differences in the ultrastructural appearance of the two particles as seen under the electron microscope (Kim and Lin 1996; Warkocki et al. 2009). An approach to understanding the molecular func- tion of Prp2 during catalytic activation is the investigation of the effect of Prp2/ ATP on the spliceosome's structure. MS analyses of various isolated spliceosomal complexes have shown that the binding of several proteins to the spliceosome is weakened by the Prp2-mediated catalytic activation. These include the proteins of the U2 SF3a and SF3b complexes which, under stringent conditions such as high salt concentration, are underrepresented in complexes $\mathrm{B}^{*}$ and $\mathrm{C}$ but not in the precatalytic complex $\mathrm{B}^{\text {act }}$ (Warkocki et al. 2009; Lardelli et al. 2010). As the U2 proteins are known to interact with pre-mRNA sequences around the branch site (BS) (Gozani et al. 1998; McPheeters and Muhlenkamp 2003), their Prp2-mediated destabilization would indicate that the structure of the catalytic core of the spliceosome near the BS is remodeled such that the BS adenosine becomes available for a nucleophilic attack at the $5^{\prime}$ SS phosphodiester bond (Warkocki et al. 2009; Lardelli et al. 2010). There are, however, potentially several other proteins whose binding affinity to the spliceosome might be changed by Prp2 action as revealed by comparative MS analysis of purified spliceosomes or by immunoprecipitation analysis (Liu et al. 2007; Chiu et al. 2009; Fabrizio et al. 2009). These include the RES (REtention and Splicing) complex proteins, the NTC-related proteins Cwc24 and Cwc27, and the essential catalytic step 1 factors Yju2 and Cwc25. Cwc24 is a zincfinger protein that is essential for viability of yeast cells and is required for pre-mRNA splicing in vivo (Goldfeder and Oliveira 2008). Cwc27 is the only spliceosomal protein containing a peptidyl-transferase domain (Ohi et al. 2002; Fabrizio et al. 2009), but it is not required for yeast viability (Winzeler et al. 1999; Giaever et al. 2002).

While the studies summarized above provide initial indications of the dynamics of the spliceosome's protein composition during its catalytic activation, their results are semiquantitative, and they yield little information about the degree of weakening or stabilization of the binding affinity of individual proteins or about the order in which proteins are bound to the spliceosome or dissociate from it. There is a need for such information, as the timing of such steps may be assumed to be crucial for the function(s) of the proteins involved. A method that appears to meet the requirements for obtaining this much-needed information is dual-color fluorescence cross-correlation spectroscopy (dcFCCS). This is a sensitive and versatile optical technique that allows the direct analysis of the dynamics of the 
association and dissociation events among proteins and/or RNAs in complex systems in solution, at low nanomolar concentrations and in equilibrium without requiring a biochemical/physical perturbation of the sample (for details, see Materials and Methods and Supplemental Material) (Kettling et al. 1998; Földes-Papp and Rigler 2001; Ohrt et al. 2011).

In this work, we have applied dcFCCS for the first time to investigate the compositional dynamics of spliceosomes from the yeast Saccharomyces cerevisiae. Specifically, we have studied the modulation of the binding strength of various proteins to the yeast spliceosome during catalytic activationthat is, during the conversion of complex $\mathrm{B}^{\text {act }}$ to complex $\mathrm{B}^{*}$. For this purpose, we have used purified $\mathrm{B}^{\text {act } \Delta \operatorname{Prp} 2}$ complexes assembled on actin pre-mRNA labeled at its $5^{\prime}$ end with the red fluorescent dye Atto647N. We were able to label proteins by fusing the protein of interest with a fluorescent protein EGFP (enhanced green fluorescent protein) by genetic modification; the fluorescently labeled protein is uniquely produced in the modified yeast strain and is, therefore, quantitatively and selectively labeled in purified spliceosomes assembled in splicing extracts derived from such strains.

We show that the binding affinity of quite a number of proteins to the spliceosome is significantly changed during Prp2-mediated catalytic activation of the spliceosome. For example, while some proteins such as Cwc24 are quantitatively displaced from the $\mathrm{B}^{\star}$ spliceosome, high-affinity binding sites are created at the same time for other proteins such as Cwc25 and Yju2. Consistent with its dynamic binding behavior during catalytic activation, we also show that Cwc24 is required for step 1 of splicing but not for catalysis per se. We, therefore, regard Cwc24 as an assembly factor for the $\mathrm{B}^{\text {act }}$ complex, involved in generating the correct $\mathrm{B}^{\text {act }}$ structure or conformation. Our data suggest substantial Prp2-mediated rearrangements of protein-RNA and/or protein-protein interactions at the catalytic core of the spliceosome. Our work also demonstrates that dcFCCS is a powerful tool, ideally suited to investigate quantitatively the compositional dynamics of the spliceosome during the splicing cycle.

\section{RESULTS}

\section{Generation of doubly labeled spliceosomes for dcFCCS measurements}

Our experimental strategy is outlined in Figure 1. The (stable) core spliceosome was tagged with the red fluorescent dye Atto647N at the $5^{\prime}$ end of actin pre-mRNA. For this purpose, a wild-type actin pre-mRNA that included three binding sites for MS2 phage coat protein upstream of the first exon (M3Act) was prepared by transcription in vitro with T7 RNA polymerase in the presence of a 10 -fold molar excess of guanosine-5'-O-monophosphorothioate (5'-GMPS) over unmodified GTP. The gel-purified pre-mRNA was then allowed to react with a 100-fold excess of Atto647N- maleimide, whereby the $5^{\prime}$-terminal phosphorothioate group of the M3Act reacted with the $\mathrm{C}=\mathrm{C}$-double bond of the maleimide group of the dye, forming, almost quantitatively, the stable thioether product Atto647N-M3Act (see Materials and Methods). We confirmed that Atto647N-M3Act was as active in a splicing assay in vitro as unmodified M3Act premRNA (Supplemental Fig. S1).

To label spliceosomal proteins, we constructed yeast strains that expressed the protein of interest with a C-terminal EGFP fusion domain and also contained a temperature-sensitive Prp2 ATPase (prp2-1) to stall spliceosome assembly at the stage of $B^{\text {act }}$ (i.e., $B^{\text {act } \Delta \text { Prp2 }}$ ) (Fig. 1). The following spliceosomal proteins were expressed stably as EGFP fusion proteins: Cus1, Prp11, and Bud13 (members of the SF3b, SF3a, and RES protein complexes, respectively), and Cwc24, Cwc27, and Yju2 (all recruited to the spliceosome during its activation). All of these proteins/complexes have an affinity for the spliceosome that potentially is modulated during the Prp2mediated transformation of $\mathrm{B}^{\text {act } \Delta \operatorname{Prp} 2}$ to the $\mathrm{B}^{\star}$ complex (see Introduction). As a control, we constructed a strain expressing an EGFP fusion of the U5 Snu114 protein, which earlier MS results showed remains stably bound to the spliceosome during the entire activation and catalytic phases (Fabrizio et al. 2009; Warkocki et al. 2009). All of these strains grew like wild-type strains and were not heat- or cold-sensitive. Moreover, extracts derived from the various strains were generally as active in splicing pre-mRNA in vitro as were extracts from strains expressing the wild-type proteins (see below, Fig. 3D). The EGFP fusion proteins were biochemically stable during splicing experiments in vitro. Generally, $<15 \%$ of the EGFP tag was degraded after purification of spliceosomes assembled on Atto647N-M3Act pre-mRNA in splicing extracts of the various strains.

For the assembly of spliceosomes that were stalled before step 1, i.e., yielding $B^{\text {act } \Delta \operatorname{Prp} 2}$ complexes, we performed splicing in vitro with Atto647N-M3Act pre-mRNA and heat-inactivated extracts derived from the yeast strains expressing the temperature-sensitive Prp2 mutant (prp2-1) and the EGFP fusion protein of a chosen spliceosomal protein (Fig. 1). The various stalled $B^{\text {act } \Delta \operatorname{Prp} 2}$ complexes were then affinitypurified with MS2-MBP fusion protein according to the recently established three-step purification procedure (Fabrizio et al. 2009; Warkocki et al. 2009). The purified spliceosomes showed a sedimentation coefficient of $\sim 45 \mathrm{~S}$ in glycerol-gradient centrifugation and contained only $\mathrm{U} 2$, U5, and U6 snRNAs and unspliced pre-mRNA, confirming that, indeed, precatalytic $\mathrm{B}^{\text {act } \Delta \operatorname{Prp} 2}$ spliceosomes were purified in each case (Warkocki et al. 2009).

\section{Stability of the binding of EGFP fusion proteins to the $B^{\text {act } \triangle P r p 2}$ complex under dcFCCS conditions}

First, essential controls were performed to ensure that the purified $\mathrm{B}^{\text {act } \Delta \operatorname{Prp} 2}$ spliceosomes behave suitably under the conditions of the dcFCCS experiments, that is, (1) they 
remain stable for at least $3 \mathrm{~h}$ at a concentration of $\sim 1 \mathrm{nM}$, and (2) they do not aggregate. We found that all the $\mathrm{B}^{\text {act } \Delta \operatorname{Prp} 2}$ complexes that contained the respective fusion proteins did, indeed, show sustained, constant high crosscorrelation between the green label and the red Atto647N dye of the pre-mRNA (shown as an example for Snu114 in Fig. $2 \mathrm{~A}$, column 1), indicating that the $\mathrm{B}^{\text {act } \Delta \operatorname{Prp} 2}$ complexes do not dissociate under these conditions.

When we induced catalytic activation of the Snu114EGFP-B ${ }^{\text {act } \Delta \operatorname{Prp} 2}$ complex by incubation with recombinant Prp2 and Spp2 plus ATP for $45 \mathrm{~min}$ at $23 \mathrm{C}^{\circ}$, we observed an almost quantitative conversion $(>90 \%)$ of the $45 \mathrm{SB}^{\text {act } \Delta \operatorname{Prp} 2}$ complex into the slower-migrating $40 \mathrm{~S} \mathrm{~B}^{\star}$ complex (as shown in Supplemental Fig. S2 for Cwc24-EGFP and also previously for unlabeled spliceosomes; Warkocki et al. 2009). In addition, we observed that the high level of crosscorrelation between Atto647N-M3Act pre-mRNA and Snu114-EGFP remained unaltered (Fig. 2A, column 2). Addition of Cwc25, which leads to C complex formation, also had no effect (column 3). This result shows that Snu114-EGFP remains stably bound in the $\mathrm{B}^{\star}$ and $\mathrm{C}$ complexes under nonstringent conditions (i.e., $75 \mathrm{mM} \mathrm{KCl}$ ).

Next, we determined whether the binding of Snu114EGFP to the spliceosome was sensitive to increasing $\mathrm{KCl}$ concentrations, both in the $\mathrm{B}^{\text {act } \Delta \operatorname{Prp} 2}$ and the $\mathrm{B}^{\star}$ complex. Figure $2 \mathrm{~B}$ (columns 1-3) shows that in the $\mathrm{B}^{\text {act } \Delta \operatorname{Prp} 2}$ complex, Snu114-EGFP remained stably bound up to $300 \mathrm{mM}$ salt, that is, no significant change in the cross-correlation was observed. At higher salt concentrations (i.e., $500 \mathrm{mM} \mathrm{KCl}$ ),
dcFCCS measurements were no longer feasible, as the spliceosomes tended to aggregate and, probably, to precipitate on the cover slide used for the dcFCCS measurements. Notably, after catalytic activation of the Snul14-EGFP$\mathrm{B}^{\text {act } \Delta \operatorname{Prp} 2}$ complexes, Snu114-EGFP remained as stably bound to the spliceosome as it was before the addition of Prp2, Spp2, and ATP (Fig. 2B, cf. columns 1-3 and 4-6). These results show that Snu114-EGFP, like native Snu114, remains stably bound to the spliceosome during catalytic activation and the first step of splicing. More importantly, they demonstrate that our highly purified yeast spliceosomes are suitable for dcFCCS-based investigation of spliceosomal protein binding during Prp2-dependent catalytic activation.

\section{Cwc24 and Cwc27 leave the spliceosome during Prp2-mediated catalytic activation under near-physiological conditions}

We first investigated the changes in Cwc24 binding upon catalytic activation of the $\mathrm{B}^{\text {act } \Delta \mathrm{Prp} 2}$ complex. To do this, we isolated the Cwc24-EGFP-B ${ }^{\text {act } \Delta \text { Prp2 }}$ complex by affinity chromatography and after elution from the amylose beads, we induced its catalytic activation by incubation with recombinant Prp2 and Spp2 plus ATP. Catalytically activated spliceosomes were then directly transferred to the observation chambers for dcFCCS measurements. Figure $3 \mathrm{~A}$, column 1, shows that the cross-correlation of $\sim 60 \%$ in the $\mathrm{B}^{\text {act } \Delta \operatorname{Prp} 2}$ complex was reduced to $<5 \%$ in the $\mathrm{B}^{*}$ complex (column 2), indicating almost quantitative dissociation of
A

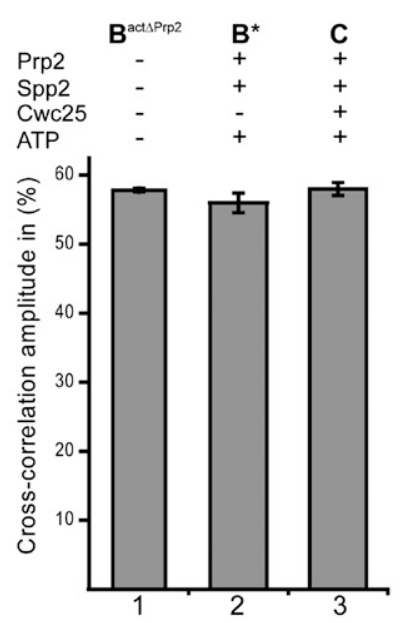

B

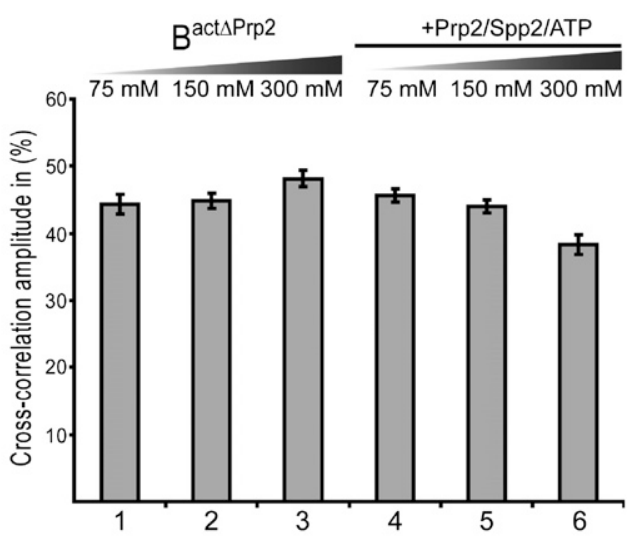

Snu114-EGFP

FIGURE 2. Binding behavior of Snu114-EGFP fusion protein to the spliceosome analyzed by dcFCCS. (A) Affinity-purified $B^{\text {act } \Delta \operatorname{Prp} 2}$ complexes assembled on Atto647N-M3Act, carrying Snu114-EGFP (column 1), were complemented with Prp2, Spp2, and ATP (column 2) and Cwc25 (column 3). After incubation ( $45 \mathrm{~min}$ at $23^{\circ} \mathrm{C}$; see Materials and Methods), dcFCCS measurements were then performed at complex concentrations of $1.0 \mathrm{nM}$. Cross-correlation amplitudes derived from two independent preparations are shown for each complex. Error bars indicate the standard deviation from two independent measurements. (B) Salt-resistance of Snu114-EGFP binding to the spliceosome during catalytic activation. Affinity-purified $\mathrm{B}^{\text {act } \Delta \operatorname{Prp} 2}$ complexes assembled on Atto647N-M3Act, carrying Snu114-EGFP (columns 1-3), were complemented with Prp2, Spp2, and ATP (columns 4-6). After the standard incubation, increasing concentrations of $\mathrm{KCl}$ were added to the samples, which were then subjected to dcFCCS measurements. 
A

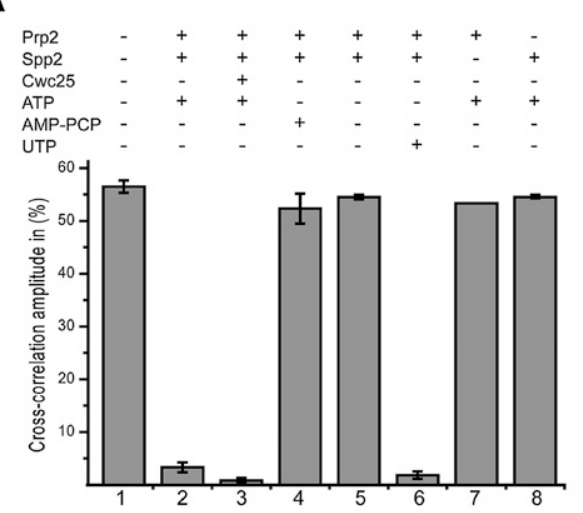

B

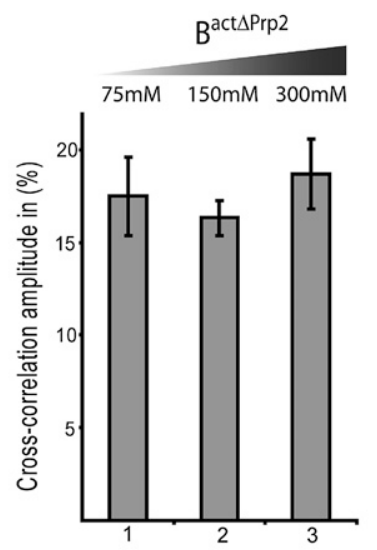

Cwc24-EGFP

C

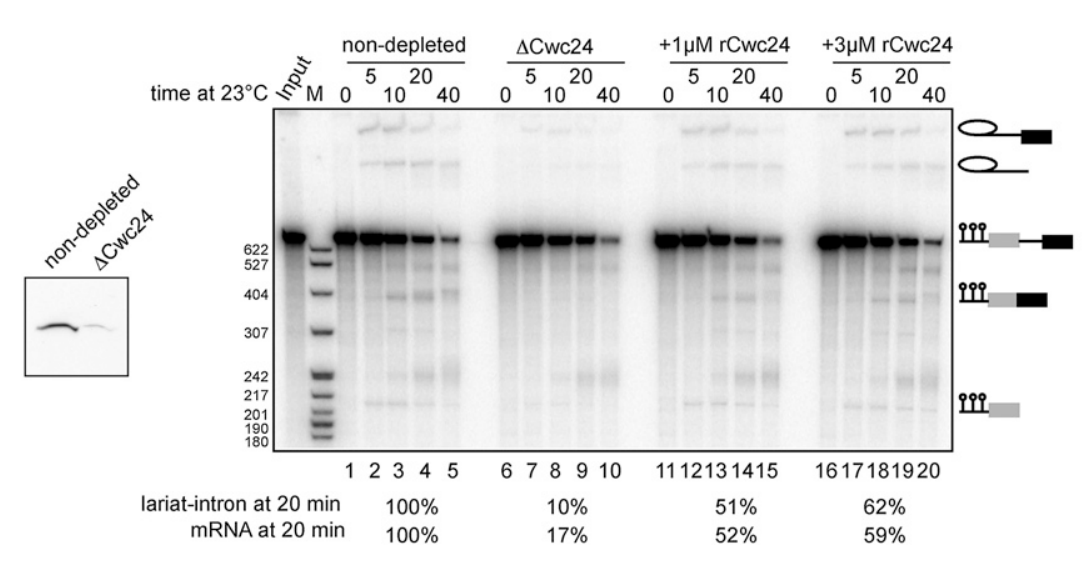

E

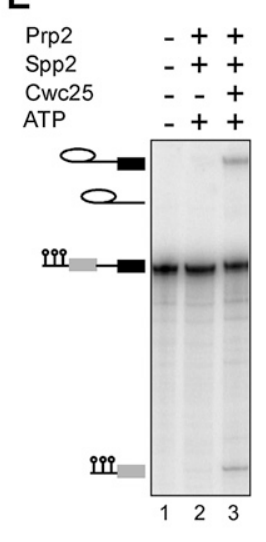

FIGURE 3. Displacement of Cwc24 from the spliceosome during Prp2-mediated catalytic activation, implying its noninvolvement in catalytic step 1 of splicing. (A) Affinity-purified $B^{\text {act } \Delta \text { Prp2 }}$ complexes assembled on Atto647N-M3Act, carrying Cwc24-EGFP (column 1), were complemented as indicated above each bar, or $(B)$ were eluted from the affinity column and incubated with increasing concentrations of $\mathrm{KCl}$ for $30 \mathrm{~min}$ on ice before dcFCCS measurements, as shown. (C) Western blot analysis of yeast splicing extracts carrying Cwc24 tagged with the TAP tag before and after depletion of Cwc24 $(\Delta \mathrm{Cwc} 24)$. $(D)$ A uniformly ${ }^{32} \mathrm{P}$-labeled M3Act pre-mRNA was incubated in yeast whole-cell extract, which was either nondepleted (lanes 1-5) or Cwc24-depleted (lanes 6-20) under standard splicing conditions. Recombinant Cwc24 was then added to a final concentration of 1 or $3 \mu \mathrm{M}$. The splicing mixtures were incubated at $23^{\circ} \mathrm{C}$ and stopped at the time indicated. RNA was analyzed on an $8 \%$ urea-polyacrylamide gel and visualized by autoradiography. The positions of the pre-mRNAs, the splicing intermediates, and products are indicated on the right. The lariat-intron and the mRNA observed after 20-min incubation were quantified using Quantity One software (BioRad), and the results are shown below the gel. (E) Affinity-purified B ${ }^{\text {act } \Delta \operatorname{Prp} 2}$ complexes assembled on ${ }^{32} \mathrm{P}-$ labeled M3Act, carrying Cwc24EGFP (lane 1), were complemented with Prp2, Spp2, and ATP (lane 2), plus the addition of Cwc25 (lane 3). The positions of the pre-mRNAs, the splicing intermediates, and products are indicated on the left.

Cwc24-EGFP. The addition of Cwc25 and formation of the $\mathrm{C}$ complex further reduced the cross-correlation amplitude (column 3). In the presence of nonhydrolyzable AMP-PCP or without ATP (columns 4-5) or without Prp2 or Spp2 (columns $7-8$ ), the cross-correlation of $\sim 60 \%$ remained unchanged. These results show that the dissociation of Cwc24-EGFP from the spliceosome accompanies the Prp2-mediated transformation of the $\mathrm{B}^{\text {act } \Delta \text { Prp } 2}$ complex into $\mathrm{B}^{\star}$. The almost complete loss of Cwc24-EGFP from the activated spliceosome is all the more notable, as this protein is very stably bound to the Cwc24-EGFP-B ${ }^{\text {act } \Delta \text { Prp } 2}$ complex, as indicated by its presence at $300 \mathrm{mM}$ salt (Fig. 3B, column 3).
The dissociation of Cwc24-EGFP during the $\mathrm{B}^{\mathrm{act} \Delta \operatorname{Prp} 2}$ to $\mathrm{B}^{\star}$ complex transition also occurred efficiently in the presence of UTP (Fig. 3A, column 6), consistent with the fact that Prp2 has a broad rNTP specificity (Kim et al. 1992). As yeast Brr2 is strictly ATP-specific, it is very unlikely that Brr2 ATPase activity is involved in the displacement of Cwc24 from the spliceosome, suggesting that this dissociation is solely due to the action of Prp2.

Cwc27 behaved in a manner similar to Cwc24 (Supplemental Fig. S3). The cross-correlation level of $\sim 12 \%$ in the Cwc27-EGFP-B ${ }^{\text {act } \Delta \operatorname{Prp} 2}$ complex fell to $<4 \%$ in the corresponding $\mathrm{B}^{\star}$ complex. As with Cwc24, this drop was seen after incubation with Prp2, Spp2, and ATP but not when 
any of these components was absent from the reaction mixture; in addition, ATP could be replaced by UTP but not by AMP-PCP. We conclude that both Cwc24 and Cwc27 lose their affinity for-or are displaced from-the spliceosome upon catalytic activation of the $\mathrm{B}^{\text {act } \Delta \operatorname{Prp} 2}$ complex.

\section{Cwc24 is essential for the first step of splicing in vitro but is not required for catalysis of the splicing reaction per se}

The above results indicate that both $\mathrm{Cwc} 24$ and $\mathrm{Cwc} 27$ dissociate almost quantitatively from the spliceosome during or after its catalytic activation, thus suggesting that they are not required for the actual first step of splicing. To test this hypothesis, we performed splicing assays with yeast cell extracts that had been depleted of Cwc24 or Cwc27. To remove Cwc24, we constructed a yeast strain that expresses Cwc24 with a C-terminal tandem affinity purification (TAP) tag (Puig et al. 2001). Splicing extracts of these cells were incubated with Sepharose beads that carried IgG (to which the TAP tag binds efficiently) or-as a "mock depletion" control-with Protein A-Sepharose beads lacking IgG. Western blotting demonstrated that Cwc24 was removed to a large extent, but not quantitatively, upon incubation with IgG-Sepharose (Fig. 3C). Furthermore, it proved impossible to remove the remaining $10 \%-15 \%$ of the TAP-tagged Cwc24 from the splicing extract by repeating the depletion procedure with fresh IgG-beads.

Yeast extracts depleted of Cwc24 ( $\Delta$ Cwc24) were then assayed for their ability to splice actin pre-mRNA. As shown in Figure 3D, the absence of Cwc24 leads-in comparison to the nondepleted extracts (lanes 1-5) - only to very small quantities of splicing intermediates or products $(\sim 10 \%-15 \%$ of the controls; lanes $6-10)$. The fact that complete inhibition is not attained can probably be ascribed to the residual Cwc24 in the $\Delta$ Cwc24 extract. After the addition of purified recombinant Cwc24, splicing of the actin pre-mRNA was restored to $\sim 60 \%$ of the level observed in the control reaction (lanes 11-20). This efficient complementation with purified Cwc24 also shows that the removal of Cwc24 was not accompanied by the coremoval of any other splicing factors in significant quantities and that the main limiting factor for the $\Delta$ Cwc24 extract's splicing efficiency in vitro is, indeed, Cwc24 itself. These results indicate that Cwc24 is required for the first step of the splicing reaction in vitro.

To determine whether Cwc24 is required for the actual catalytic step, affinity-purified $\mathrm{B}^{\text {act } \Delta \text { Prp2 }}$ complexes assembled on ${ }^{32} \mathrm{P}$-labeled M3Act pre-mRNA (Fig. 3E, lane 1) were complemented with Prp2, Spp2, and ATP to allow the dissociation of Cwc24 (lane 2). Cwc25 was then added (lane 3). The spliceosomes from which Cwc24 had dissociated (Fig. 3A, column 3), were capable of carrying out catalytic step 1 of splicing (Fig. 3E, lane 3), supporting the idea that Cwc24 is required before the action of Prp2 and not for catalytic step 1 per se.

In the same way, we investigated whether the removal of Cwc27 from splicing extracts obtained from yeast cells that express TAP-tagged Cwc27 leads to an inhibition of premRNA splicing in vitro. In this case, the removal of Cwc27 with IgG beads was almost quantitative (Supplemental Fig. S4A); however, actin pre-mRNA was spliced just as efficiently as in the mock-depleted extract (Supplemental Fig. S4B). Therefore, Cwc27 is not required for splicing in vitro under standard conditions, a result consistent with the finding that Cwc27 is also not essential for the growth of yeast under normal physiological conditions (Winzeler et al. 1999; Giaever et al. 2002).

\section{The binding of the RES complex protein Bud13 is weakened during catalytic activation}

The cross-correlation level of Bud13-EGFP-B ${ }^{\text {act } \Delta \text { Prp2 }}$ under stringent conditions ( $300 \mathrm{mM} \mathrm{KCl}$ ) was reduced by $\sim 50 \%$ (Fig. 4, columns 1-3), indicating that the binding of Bud13EGFP to the $\mathrm{B}^{\text {act } \Delta \operatorname{Prp} 2}$ spliceosome was considerably weaker than that of Snu114 or Cwc24. More importantly, Prp2mediated catalytic activation of the Bud13-EGFP- $\mathrm{B}^{\text {act } \Delta \operatorname{Prp} 2}$ complexes reduced significantly the affinity of Bud13-EGFP for the $\mathrm{B}^{\star}$ complex, such that $>60 \%$ of the protein was found to be dissociated at the relatively low salt concentration of 75 $\mathrm{mM}$ (Fig. 4, cf. columns 1 and 4). This reduction in crosscorrelation was not observed in the presence of AMP-PCP (data not shown). The bound fraction appeared to retain some degree of binding affinity, as only $\sim 60 \%$ of the Bud13EGFP remaining bound to the spliceosome after catalytic activation was displaced by high salt (Fig. 4 , cf. columns 2 and 5,3 and 6).

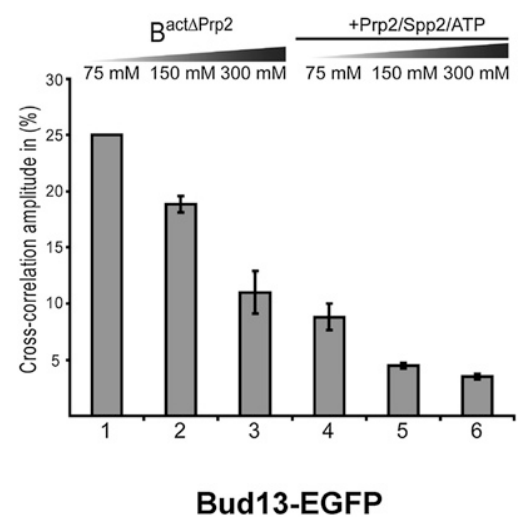

FIGURE 4. Displacement of Bud13-EGFP from the spliceosome during Prp2-mediated catalytic activation. Affinity-purified $B^{\text {act } \Delta \text { Prp2 }}$ complexes assembled on Atto647N-M3Act, carrying Bud13-EGFP (columns 1-3), were complemented with Prp2, Spp2, and ATP (columns 4-6). After incubation, $\mathrm{KCl}$ was added in increasing concentrations, and dcFCCS was performed as above. 
The U2-associated SF3a and SF3b proteins Prp11 and Cus 1 remain bound to the $B^{*}$ complex under physiological conditions, but their affinity is weakened at high salt

There is disagreement in the literature as to the binding behavior of the $\mathrm{U} 2 \mathrm{SF} 3 \mathrm{a} / \mathrm{b}$ proteins during the catalytic phase of the yeast spliceosome. Depending on the conditions under which the catalytically active spliceosomes are isolated, these proteins are reported to be "completely absent" to "stoichiometrically present" (see Discussion). We, therefore, used dcFCCS to examine the representative proteins Prp11-EGFP (for U2 SF3a) and Cus1-EGFP (for SF3b) in B ${ }^{\text {act } \Delta \text { Prp2 }}$ and $B^{\star}$ complexes. Figure 5 shows that both proteins remain bound to their respective $\mathrm{B}^{\text {act } \Delta \operatorname{Prp} 2}$ complexes up to $300 \mathrm{mM}$ salt, as also observed for Snu114-EGFP and Cwc24 (columns 1-3).

However, incubation of the affinity-purified $\mathrm{B}^{\star}$ complexes with increasing concentrations of $\mathrm{KCl}$ resulted in destabilization of both proteins; at $150 \mathrm{mM}$ salt, a $20 \%$ reduction in cross-correlation was observed, whereas at $300 \mathrm{mM}$, a major fraction $(\sim 70 \%)$ had dissociated from the spliceosome. This contrasts with the behavior of Snu114-EGFP, which remained stably bound to the $\mathrm{B}^{\star}$ complex even at $300 \mathrm{mM}$ $\mathrm{KCl}$ (Fig. 2B). Thus, the U2 SF3a/b proteins are strongly bound to the precatalytic spliceosome, but their binding is weakened by the catalytic activation of the spliceosome, becoming salt-sensitive. Nevertheless, their affinity for the $\mathrm{B}^{\star}$ spliceosome is considerably higher than that observed for Cwc24, Cwc27, and Bud13. At $75 \mathrm{mM} \mathrm{KCl}$, Cus1 and Prp11 did not dissociate after addition of recombinant Cwc25, i.e., upon $\mathrm{C}$ complex formation (data not shown).

\section{Binding of Yju2 to the spliceosome is strengthened upon catalytic activation}

Though Yju2 is recruited to the spliceosome before the Prp2-mediated step, it appears to have a low affinity for the
$\mathrm{B}^{\text {act } \Delta \operatorname{Prp} 2}$ complex, as evidenced by its sensitivity to ionic strength; more than half of Yju2-EGFP dissociated from the $\mathrm{B}^{\text {act } \Delta \operatorname{Prp} 2}$ complex already at $150 \mathrm{mM} \mathrm{KCl}$ (Fig. 6, columns 1,2 ), and at higher salt, dissociation was complete (column 3). However, upon catalytic activation by Prp2, the binding of Yju2-EGFP to the $\mathrm{B}^{\star}$ complex was stabilized when compared to its binding to the corresponding $\mathrm{B}^{\text {act } \Delta \operatorname{Prp} 2}$ complex (Fig. 6, cf. columns 4 and 1). This increased binding affinity for the $\mathrm{B}^{*}$ complex was more pronounced at $150 \mathrm{mM}$ (columns 2,5) and $300 \mathrm{mM}$ (columns 3,6) KCl. Addition of Cwc25, leading to the $\mathrm{C}$ complex, had no additional effect (columns 7-9). We conclude that the Prp2-dependent rearrangement of the spliceosome changed the binding affinity of Yju2 for the spliceosome from low to high. Moreover, the affinity of Yju2 for the $\mathrm{B}^{\star}$ complex was minimally affected by the first step of splicing.

\section{Catalytic activation by Prp2 creates a high-affinity binding site for Cwc25 in the spliceosome}

We have shown above that, as a result of Prp2-mediated ATPase activity, the affinity of many proteins for the spliceosome changes significantly such that they are either displaced (Cwc24, Cwc27, Bud13), or their affinity is destabilized (U2 $\mathrm{SF} 3 \mathrm{a} / \mathrm{b}$ ) or even enhanced (Yju2). The remodeled $\mathrm{B}^{\star}$ complex then, in conjunction with the catalytic step 1 factor Cwc25, catalyzes the first step of the splicing reaction (Warkocki et al. 2009). As a prerequisite to investigating the binding behavior of Cwc25 to the spliceosome during its catalytic activation in more detail, we conjugated the green fluorescent dye Alexa $488 \mathrm{~N}$-maleimide to Cwc25 via cysteines which were introduced at the $\mathrm{N}$ or $\mathrm{C}$ terminus of Cwc25. After labeling the overexpressed and purified protein, a second round of purification was performed to eliminate unbound Alexa488Nmaleimide, and fluorescent Cwc25 was obtained with a labeling efficiency of $\sim 70 \%$ (see Materials and Methods).
A

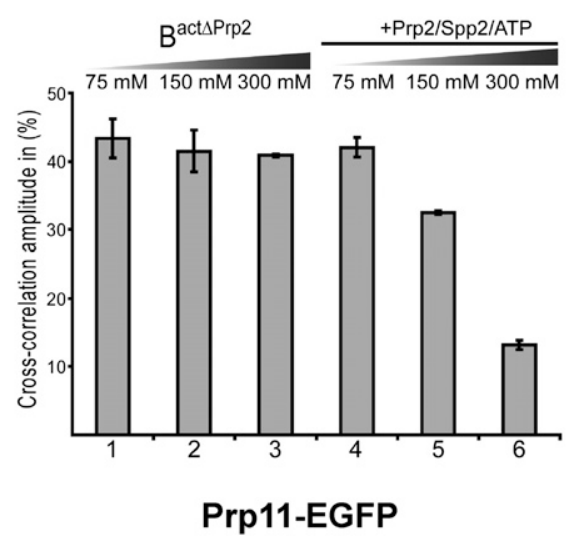

B

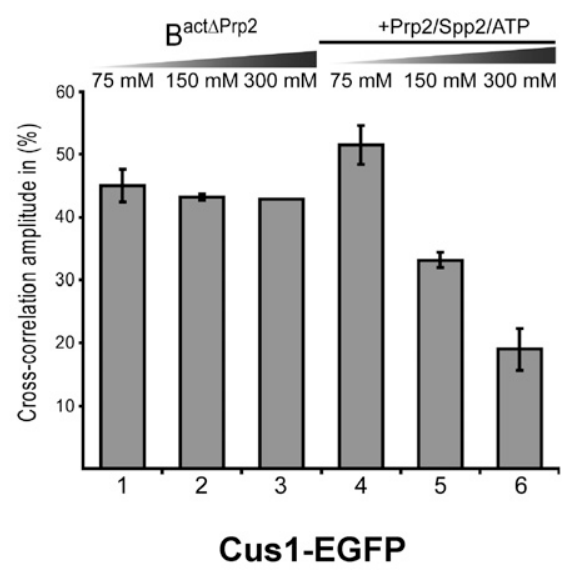

FIGURE 5. Binding of U2 SF3a/b proteins Prp11-EGFP and Cus1-EGFP to the spliceosome is made salt-sensitive by the catalytic activation. Affinity-purified $B^{\text {act } \Delta \operatorname{Prp} 2}$ complexes were assembled on Atto647N-M3Act, carrying Prp11-EGFP $(A)$ or Cus1-EGFP $(B)$. The complexes were incubated with increasing salt concentration before (columns 1-3) or after (columns 4-6) complementation with Prp2, Spp2, and ATP. 


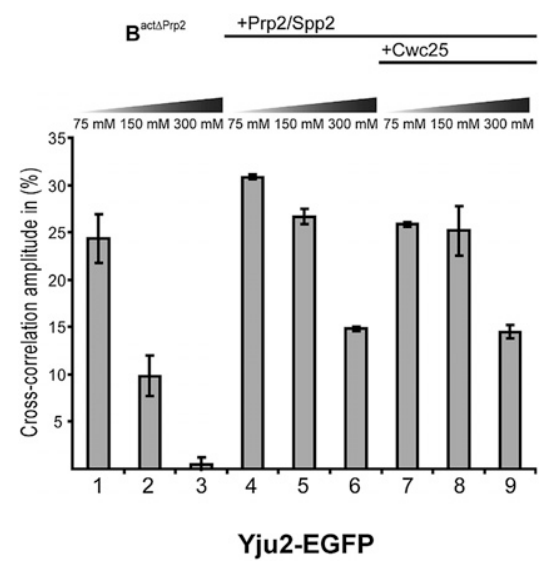

FIGURE 6. Strengthening of binding of Yju2-EGFP to the spliceosome upon catalytic activation. Affinity-purified $\mathrm{B}^{\text {act } \Delta \operatorname{Prp} 2}$ complexes assembled on Atto647N-M3Act, carrying Yju2-EGFP (columns 1-3), were complemented with Prp2, Spp2, and ATP (columns 4-6), or with Prp2, Spp2, ATP, and Cwc25 (columns 7-9). After standard incubation, increasing concentrations of $\mathrm{KCl}$ were added.

To test whether fluorescently labeled Cwc25 is functional, we purified $\mathrm{B}^{\text {act } \Delta \operatorname{Prp} 2}$ complexes assembled on Atto647NM3Act pre-mRNA and complemented them with Prp2, Spp2, ATP, and either unlabeled Cwc 25 or its $\mathrm{N}$ or $\mathrm{C}$ terminuslabeled versions. Supplemental Figure S1 shows that all Cwc25 preparations tested led to equal step 1 efficiencies.
Next, we studied the recruitment of Cwc25 to the spliceosome in more detail. Purified $\mathrm{B}^{\text {act } \Delta \operatorname{Prp} 2}$ complexes assembled on Atto647N-M3Act were complemented with Prp2, Spp2, Cwc25-Alexa488 (C-terminally labeled) and ATP or solely with Cwc25-Alexa488. Reaction mixtures were incubated for $45 \mathrm{~min}$ at $23^{\circ} \mathrm{C}$ and analyzed by dcFCCS (Fig. 7A). $\mathrm{B}^{\text {act } \Delta \operatorname{Prp} 2}$ complexes complemented with Cwc25-Alexa488 exhibited only a background cross-correlation of $<5 \%$ (column 2). However, when the $B^{\text {act } \Delta \operatorname{Prp} 2}$ complex was supplemented with Prp2, Spp2, ATP, and Cwc25-Alexa488, it showed a cross-correlation amplitude of $\sim 50 \%$. Thus, Cwc25 binds efficiently to the spliceosome only after ATP-hydrolysis by Prp2 and, as shown above, the release or destabilization of several proteins. In turn, this suggests that the remodeling of the spliceosome by Prp2 creates a binding site for Cwc25 in the spliceosome.

To study how the affinity of Cwc25 changes during catalytic activation of the spliceosome, we determined quantitatively the binding constants for $\mathrm{Cwc} 25$ at the $\mathrm{B}^{\text {act } \Delta \operatorname{Prp} 2}$ and $\mathrm{B}^{*}$ stages, i.e., immediately before and after catalytic activation by Prp2. B ${ }^{\text {act } \Delta \operatorname{Prp} 2}$ complexes assembled on Atto647N-M3Act were purified and retained on amylose columns. They were then eluted, either directly or after conversion to $B^{*}$ complexes, on the matrix by addition of Prp2, Spp2, and ATP. Both complexes were then used for binding studies with Cwc25-Alexa488. Increasing amounts of $B^{\text {act } \Delta \operatorname{Prp} 2}$ or $\mathrm{B}^{\star}$ complexes were added to a fixed concentration of
A

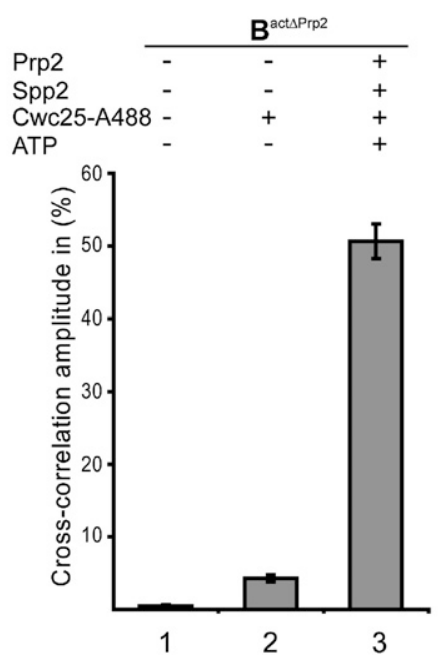

B

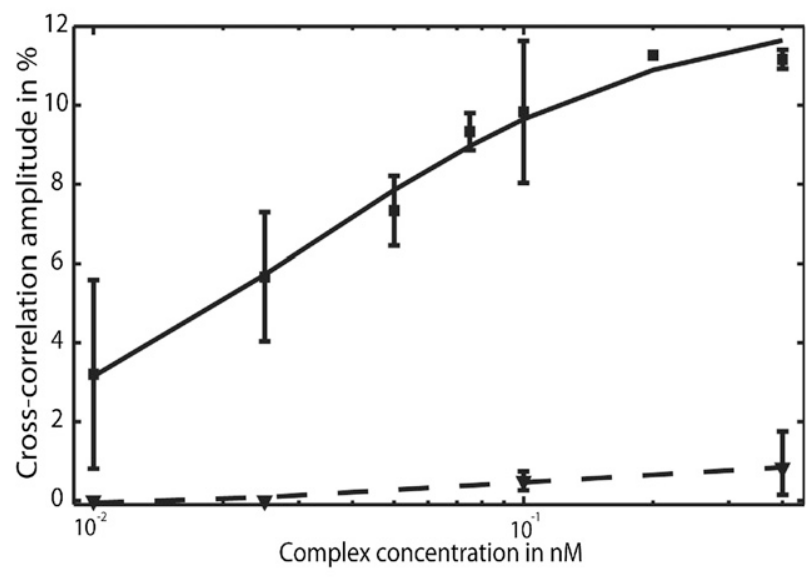

FIGURE 7. Catalytic activation by Prp 2 creates a high-affinity binding site for Cwc 25 in the spliceosome. $(A) \mathrm{B}^{\text {act } \Delta \operatorname{Prp} 2}$ complexes assembled on Atto647N-M3Act (column 1) were complemented on the amylose matrix with C-terminally labeled Cwc25-Alexa488 (column 2) or Cwc25Alexa488 together with Prp2, Spp2 plus ATP (column 3). After incubation, the complexes were washed and eluted with maltose, and dcFCCS measurements were performed. $(B) \mathrm{B}^{\text {act } \Delta \mathrm{Prp} 2}$ complexes assembled on Atto647N-M3Act were directly eluted from the amylose matrix or activated on the column by Prp2 and Spp2 in the presence of ATP to generate $B^{\star}$ before the elution. Increasing amounts of complexes were then

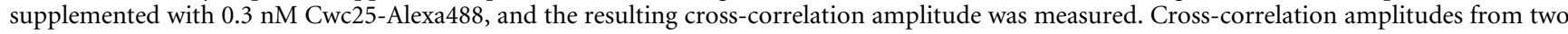
independent measurements were plotted against the respective complex concentration (Hill plot, semilogarithmic scale). Curve-fitting revealed a dissociation constant of Cwc25-Alexa488 to complex B $\mathrm{B}^{*}$ of $K_{\mathrm{d}}=0.03 \mathrm{nM}$. The lower curve was obtained under similar conditions but by adding complex $B^{\text {act } \Delta \operatorname{Prp} 2}$ instead of $B^{*}$. 
Cwc25-Alexa488 (0.3 nM). Figure 7B shows the dependences of the resulting cross-correlation amplitudes upon complex concentration. A subsequent fit to the Hill equation yielded a binding (dissociation) constant $K_{\mathrm{d}}$ of $0.03 \mathrm{nM}$ for Cwc25-Alexa488 interaction with the $\mathrm{B}^{\star}$ complex, indicating a very strong binding. We conclude that the Prp2-dependent rearrangement of the spliceosome generates a high-affinity binding site for Cwc25.

\section{DISCUSSION}

\section{Suitability of dcFCCS for investigating spliceosomal protein dynamics}

The experiments described provide "proof of principle" that dcFCCS, in combination with the in vitro reconstitution of functional spliceosomes, is, indeed, a powerful approach for investigating purified spliceosomes. The basic criteria of adequate stability in the measuring device and of nonaggregation under dcFCCS conditions (several hours at $\sim 1 \mathrm{nM}$ concentration in the hermetically sealed observation chamber under laser excitation) (Fig. 2) can easily be checked in a given system. In this study, the first fluorescent label needed for observing cross-correlation was introduced by coupling the Atto647 dye covalently to the $5^{\prime}$ end of the actin pre-mRNA, and the second by fusing the protein of interest with the green fluorescent protein EGFP by genetic modification. The resulting doubly fluorescent-labeled, purified spliceosomal complexes were found to be stable under our dcFCCS conditions.

As in any study involving the introduction of bulky labels, there is a risk of label-induced artefactual behavior. In the system described here, neither the label on the premRNA nor those on the various proteins impaired the activity of the spliceosomes examined. Furthermore, the use of Snu114-EGFP, which binds to the spliceosome throughout the splicing cycle, as a "positive control" confirmed that our purified spliceosomes were sufficiently stable, and the results were sufficiently reproducible, to allow the investigation of the binding and release of other proteins.

\section{Prp2-mediated transformation of the $\mathrm{B}^{\text {act }}$ into the $B^{*}$ complex substantially alters the binding affinity of several proteins at the catalytic core of the spliceosome}

Although the essential role of Prp2 in the catalytic activation of the spliceosome was established more than a decade ago, its mechanism of action has remained enigmatic (Kim and Lin 1996). The structural change the spliceosome undergoes upon Prp2-mediated, ATP-dependent activation must be profound, given the substantial change in $S$ value seen between the precursor $\mathrm{B}^{\text {act } \Delta \operatorname{Prp} 2}$ complex (45S) and the catalytically activated spliceosome $\mathrm{B}^{\star}(40 \mathrm{~S})$ (Kim and Lin 1996; Warkocki et al. 2009). Here, we show by dcFCCS that the binding affinity of at least seven proteins, i.e., the U2 SF3a/b proteins Prp11 and Cus1, the RES complex protein Bud13, Cwc24, Cwc27, Yju2, and Cwc25, is quantitatively and qualitatively altered by Prp2-mediated catalytic activation of the spliceosome. These proteins fall into three groups: The first group comprises Cwc24, Cwc27, and Bud13, which are firmly bound to the $\mathrm{B}^{\text {act } \Delta \text { Prp2 }}$ spliceosome and yet dissociate even under near-physiological (nonstringent) conditions either almost quantitatively (Cwc24 und Cwc27) or largely (Bud13) upon conversion to $\mathrm{B}^{\star}$, that is, their binding affinity is strongly decreased or they are physically displaced. The second group comprises the SF3a/b proteins Prp11 and Cus1, whose binding to the spliceosome is destabilized but not abolished during catalytic activation, such that they dissociate from the $\mathrm{B}^{*}$ complex at higher salt concentrations while remaining bound under near-physiological conditions (Fig. 5). The third group contains proteins whose binding to the spliceosome is enhanced during the $\mathrm{B}^{\text {act } \Delta \operatorname{Prp} 2}$ to $\mathrm{B}^{*}$ transition and includes Yju2 (which before the transition is more weakly bound) and Cwc25 (which before the transition was not bound at all and is thus recruited to $B^{\star}$ ). Both proteins are known to be required for the first catalytic step that is catalyzed by complex $\mathrm{B}^{\star}$.

\section{Cwc24 functions in the generation of an active spliceosome but is not required for splicing catalysis per se}

Our finding that Cwc24 and Cwc27 dissociate almost quantitatively from the spliceosome during or after the Prp2-mediated catalytic activation of the spliceosome (Fig. 3; Supplemental Fig. S3) was a first indication that they are likely not required for catalysis of the splicing reaction per se. Little is known about the function of Cwc24 and Cwc27 in splicing. Cwc27 contains a peptidylprolyl isomerase domain and also has an evolutionarily conserved counterpart in the human spliceosome, NYCO10 (Ohi et al. 2002; Fabrizio et al. 2009). However, Cwc27 does not seem to be essential for the growth of $S$. cerevisiae under standard conditions (Winzeler et al. 1999; Giaever et al. 2002). In contrast, Cwc24 is known to be essential for yeast growth, and it is needed for the splicing of U3 pre-RNA in vivo (Goldfeder and Oliveira 2008). Therefore, we investigated the role of Cwc24 in splicing in more detail.

The depletion/reconstitution experiments described here, indeed, confirmed that the presence of Cwc24 is necessary for splicing to proceed through the first catalytic step in vitro. Remarkably, they also showed that Cwc24 is not required for the actual catalysis; catalytically activated $\mathrm{B}^{*}$ complexes that had lost all of their Cwc24 were still able to perform the first catalytic step of splicing efficiently when complemented with the step 1 factor Cwc25 (Fig. 3E). Thus, the function of Cwc24 must be to assist in the assembly or the maturation of the activated spliceosome. We, therefore, regard Cwc24 as an assembly factor for the 
$\mathrm{B}^{\text {act }}$ complex that is likely involved in generating the correct structure or conformation of the $\mathrm{B}^{\text {act }}$ complex. It will, therefore, be interesting to find out with which proteins of the $\mathrm{B}^{\text {act }}$ complex Cwc24 is in direct contact and whether it also binds to spliceosomal RNAs.

The RES proteins, though not essential for yeast viability, are required for efficient splicing in vitro and in vivo. Moreover, inactivation of these proteins causes leakage of unspliced pre-mRNA from the nucleus (Dziembowski et al. 2004). We showed earlier that the RES complex is recruited efficiently to complex B and is stoichiometrically present in $B^{\text {act }}$ (Fabrizio et al. 2009). The present results show that the RES protein Bud13 loses its affinity for the $\mathrm{B}^{\star}$ complex. This finding is consistent with the idea that the RES proteins remain associated with the spliceosome-preventing the premature nuclear release of unspliced pre-mRNA - until Prp2mediated catalytic activation commits the spliceosome to the first catalytic step.

\section{$\mathrm{SF} 3 \mathrm{a} / \mathrm{b}$ proteins remain bound to the $\mathrm{B}^{*}$ spliceosome under near-physiological conditions, but their binding is reduced at high salt}

Our dcFCCS data show clearly that ATP hydrolysis by Prp2 also affects the binding affinity of the SF3a/b Prp11 and Cus1 proteins (Fig. 5). Although SF3a/b proteins remain bound at physiological salt, destabilization of their interaction was confirmed by loss of binding affinity at high salt. In human $\mathrm{B} / \mathrm{B}^{\text {act }}$ complex, several $\mathrm{SF} 3 \mathrm{a} / \mathrm{b}$ proteins bind to the pre-mRNA on both sides of the BS (Gozani et al. 1998), and a similar function may provisionally be ascribed to their counterparts in yeast. Indeed, Hsp155, the yeast homolog of human SF3b 155, cross-links to pre-mRNA close to the BS (McPheeters and Muhlenkamp 2003). Thus, the destabilization of these proteins' binding by Prp2/ATP involves rearrangement of the spliceosome near the BS, which could expose the BS adenosine for nucleophile attack at the $5^{\prime}$ SS phosphodiester bond.

There are somewhat conflicting reports regarding the fate of the U2-associated SF3a/b proteins during catalytic activation. In early work (Fabrizio et al. 2009), we used MS to characterize the proteomes of $\mathrm{B}, \mathrm{B}^{\text {act }}$, and $\mathrm{C}$ complexes affinity-purified from yeast whole-cell extracts and found that, although the U2 SF3a/b proteins were represented in similar quantities in $\mathrm{B}$ and $\mathrm{B}^{\text {act }}$, in the $\mathrm{C}$ complex their presence was reduced to $20 \%-30 \%$. However, when $B^{*}$ and $\mathrm{C}$ complexes were prepared from $\mathrm{B}^{\text {act } \Delta \mathrm{Prp} 2}$ by complementation in vitro, the same $\mathrm{U} 2$ proteins were found by MS to be similarly abundant in the $\mathrm{B}^{\text {act } \Delta \operatorname{Prp} 2}, \mathrm{~B}^{\star}$, and $\mathrm{C}$ complexes (Warkocki et al. 2009). In a recent paper (Lardelli et al. 2010), it was reported that endogenous yeast $C$ complexes arrested in vivo by the effect of a cold-sensitive Prp16 mutant and subsequently purified from whole yeast extracts contained virtually no U2 proteins. In the present work, we found that, under dcFCCS conditions (i.e., spliceosomes reconstituted in vitro under near-physiological conditions and at $\sim 1 \mathrm{nM}$ concentration), the $\mathrm{U} 2$ proteins Prp11 and Cus1 are not released either from complex $\mathrm{B}^{\star}$ or from complex C. We believe that the results shown here correspond most closely to physiological reality because dcFCCS allows spliceosomes to be investigated directly in solution and in equilibrium without requiring biochemical/ physical perturbation of the sample.

The differences described above could be due simply to the U2 proteins having an intermediate binding affinity after catalytic activation of the spliceosome so that their continued presence in $\mathrm{B}^{\star}$ and/or $\mathrm{C}$ complexes is sensitive to small changes in the spliceosome's physical environment (including the presence of numerous other biomacromolecules, as is the case in vivo and in vitro in whole-cell extracts). Since in all cases, either truncated pre-mRNAs or mutated RNA helicases were used to arrest the spliceosome at the desired stage, it is also conceivable that, in extract, discard mechanisms are responsible for the removal of the U2 proteins from dead-end spliceosomal complexes. It is also possible that the spliceosome's function after its transition to complex $\mathrm{B}^{\star} / \mathrm{C}$ is not influenced, positively or negatively, by the presence of residual U2 proteins. Alternatively, the U2 proteins may, indeed, remain bound to the spliceosome in the $\mathrm{B}^{\star} / \mathrm{C}$-complex stage in vivo and have some function there, as yet unknown. It will, thus, be interesting to investigate whether in our hands the SF3a/b proteins remain bound to the spliceosome during the entire spliceosomal cycle.

\section{Prp2 action creates high-affinity binding sites for the catalytic step 1 factors Yju2 and Cwc25 in the catalytically activated spliceosome}

The ATP-dependent Prp2-driven activation of the spliceosome leads not only to the dissociation or destabilization of many proteins but also to the binding or stabilization of others. An example of the latter is Yju2. Of all of the proteins studied here by dcFCCS, Yju2 has the lowest affinity for the $\mathrm{B}^{\text {act } \Delta \operatorname{Prp} 2}$ spliceosome and can be completely removed from it at $300 \mathrm{mM}$ salt. After Prp2-mediated catalytic activation, the spliceosome's binding affinity for Yju2 is strongly enhanced, and its association becomes largely salt-resistant. Furthermore, a strong binding site is created in the $\mathrm{B}^{\star}$ spliceosome for the step 1 factor Cwc25. While Cwc25 only shows background binding to complex $\mathrm{B}^{\text {act } \Delta \operatorname{Prp} 2}$, its binding to complex $\mathrm{B}^{\star}$ has a $K_{\mathrm{d}}$ value in the subnanomolar range. It has been suggested that Yju2 may be involved in recruiting Cwc25 (Chiu et al. 2009), an idea in agreement with our finding that a high-affinity binding site for Yju2 is created by Prp2 action. However, we were unable to detect any binding between isolated, recombinant Yju2 and Cwc25 proteins in pulldown experiments (data not shown). Site-directed, cross-linking studies should help to clarify this interesting question in the future. 


\section{Cooperativity of the Prp2-mediated remodeling process during catalytic activation of the spliceosome}

In this first dcFCCS analysis of spliceosomes, we have measured the effect of the $\mathrm{B}^{\text {act } \Delta \operatorname{Prp} 2}$ to $\mathrm{B}^{\star}$ transition on the binding strengths of seven proteins. Of these, Bud13, Prp11, and Cus1 all belong to multiprotein complexes containing two (RES and SF3a) or six (SF3b) additional proteins. Our earlier MS analyses showed that binding of proteins in each of these complexes is weakened to a comparable extent, consistent with the dcFCCS results presented here. This implies that the interactions of at least 17 proteins with the spliceosome are modified via Prp2-mediated catalytic activation (see Fig. 8 for a schematic). The final number will certainly be greater; for example, the binding of Prp2 and of Spp2 is also known to be weakened during catalytic activation (King and Beggs 1990; Kim and Lin 1996).

In view of these comprehensive structural rearrangements at the catalytic core of the spliceosome, one may reasonably ask whether Prp2 alone is responsible for this entire remodeling process, or whether other ATPases may also be involved. Our MS analysis of the isolated $B^{\text {act } \Delta \operatorname{Prp} 2}$ complex showed the complete absence of the RNA helicases Prp5, Sub2, and Prp28, which are required for earlier steps of spliceosome assembly (Warkocki et al. 2009). The only spliceosomal helicase that is stoichiometrically present in $\mathrm{B}^{\text {act }}$ complex is Brr2, which-together with the GTPase Snu114-triggers the precatalytic activation of the spliceosome by disrupting U4/U6 interaction (Bartels et al. 2002; Small et al. 2006). It was recently shown that the obligate ATPase Brr2, together with Prp43, functions in the dissociation of the post-splicing complexes that contain the intron lariat (Arenas and Abelson 1997; Small et al. 2006), suggesting that Brr2 could, perhaps, also be involved in catalytic activation, together with Prp2. However, we demonstrated earlier that the Prp2-dependent shift in $S$ value from $\sim 45 S$ to $\sim 40 S$ during catalytic activation takes place in the presence of all rNTPs (not only ATP) (Warkocki et al. 2009). Here, we show that the Prp2-dependent dis-
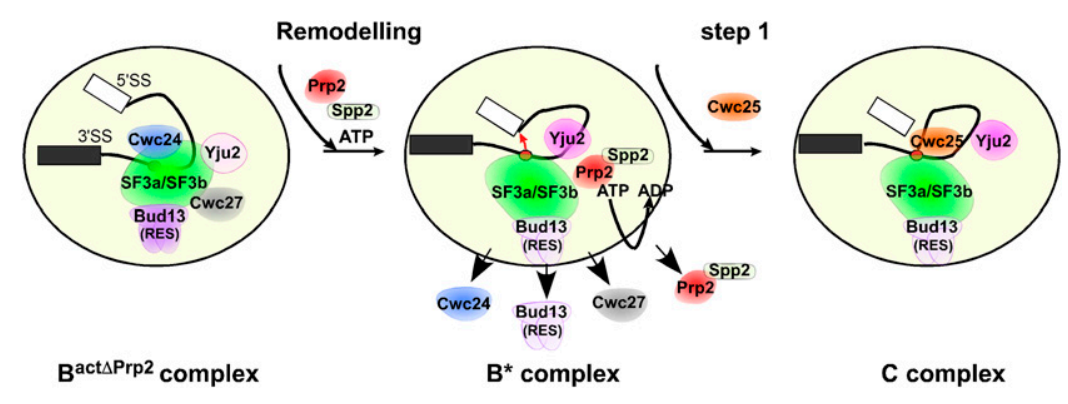

FIGURE 8. Schematic representations of the substantial remodeling the $\mathrm{B}^{\text {act } \Delta \operatorname{Prp} 2}$ spliceosome undergoes during the Prp2/ATP-mediated catalytic activation. Cwc24, Cwc27, the RES protein Bud13, Prp2, and Spp2 are released, while the U2 SF3a/b proteins are destabilized by Prp2/ ATP, such that the BS adenosine becomes available for a nucleophile attack at the $5^{\prime}$ SS phosphodiester bond. At the same time, high-affinity binding sites are created for Yju2 and Cwc25, which are required to promote the first step of splicing. sociation of individual proteins, such as Cwc24-EGFP, occurs in the presence of UTP with an efficiency equal to that in the presence of ATP (Fig. 3). As yeast Brr2 hydrolyzes ATP and no other rNTP, while Prp2 is rNTPunspecific (Kim et al. 1992), a contribution of the Brr2 ATPase activity to spliceosome remodeling during catalytic activation seems very unlikely. This would mean that Prp2 alone is responsible for the many changes in molecular interactions that take place during the transformation of $\mathrm{B}^{\text {act } \Delta \operatorname{Prp} 2}$ into the $\mathrm{B}^{\star}$ spliceosome.

This, in turn, suggests a high degree of cooperativity during the Prp2-mediated $\mathrm{B}^{\text {act } \Delta \operatorname{Prp} 2}$ to $\mathrm{B}^{\star}$ complex transition. In a highly cooperative model, it would be conceivable that Prp2 only has a single substrate-that is, only one protein is displaced from the network of intermolecular interactions in the $\mathrm{B}^{\text {act } \Delta \operatorname{Prp} 2}$ complex and that this triggers all subsequent rearrangements. A possible Prp2 target could be Cwc24, as it is very stably bound in the $\mathrm{B}^{\text {act } \Delta \operatorname{Prp} 2}$ complex but loses its binding affinity during the transition to the $\mathrm{B}^{*}$ complex (Fig. 3). In this context, the recent demonstration of a direct interaction between Cwc24 and Cef1 is of interest (Goldfeder and Oliveira 2008). Cef1 is a core protein of the NTC complex, which acts as a major assembly platform, integrating and coordinating many molecular interactions in $\mathrm{B}^{\text {act }}$ and $\mathrm{B}^{\star}$ complexes (Tsai et al. 1999; Hogg et al. 2010). An alternative primary target of Prp2 could be one of the U2 $\mathrm{SF} 3 \mathrm{a} / \mathrm{b}$ proteins, which are known to interact with the premRNA near the BS. We cannot entirely exclude, however, that Prp2 may act on a number of targets, altering in succession the binding affinities of various proteins. This question could potentially be answered by performing a time-resolved analysis of the dissociation of various proteins and by determining the number of ATP molecules that are hydrolyzed during the transformation of a $\mathrm{B}^{\text {act } \Delta \operatorname{Prp} 2}$ to a C complex. It is also unclear which RNA structure(s) in the spliceosome is/are the primary target(s) of Prp2/ATPase activity or whether Prp2 affects protein-protein interactions directly. Prp2 has been cross-linked to the region between the BS and the 3' SS (Teigelkamp et al. 1994), raising the possibility that Prp2 modulates interactions between the BS region and the $\mathrm{U} 2$ proteins. Alternatively, contact with this stretch of RNA might merely be required to stimulate Prp2/ATPase activity. It is also possible that Prp2/ATPase activity modulates the U2 RNA conformation during catalytic activation (Hilliker et al. 2007; Perriman and Ares 2007), which, in turn, could lead to the rearrangement of protein-RNA and protein-protein interaction at the catalytic core. Clearly, more information is needed about the direct contact sites of Prp2 on the $\mathrm{B}^{\text {act } \Delta \operatorname{Prp} 2}$ spliceosome and about the timing of the Prp2-mediated structural 
changes of the spliceosome to understand this important and profound structural reorganization step. The study described here shows that dcFCCS can contribute significantly to these sophisticated investigations using reconstituted, highly purified spliceosomes.

\section{MATERIALS AND METHODS}

\section{Splicing reconstitution assay}

$\mathrm{B}^{\text {act } \Delta \text { prp2 }}$ spliceosomes ( $60 \mathrm{fmol}$, end concentration $1 \mathrm{nM}$ ) were eluted from the amylose matrix in buffer G-75 (20 mM HEPES$\mathrm{KOH}$ (pH 7.9), $1.5 \mathrm{mM} \mathrm{MgCl}$, 5\% glycerol, 0.01\% NP40, $75 \mathrm{mM}$ $\mathrm{KCl}, 0.5 \mathrm{mM}$ DTT, and $0.5 \mathrm{mM}$ PMSF) and were combined with recombinant proteins ( $600 \mathrm{fmol}$, end concentration $10 \mathrm{nM}$ ), buffer G-75, $2.5 \mathrm{mM} \mathrm{MgCl}_{2}, 2.0 \mathrm{mM}$ ATP or $2.0 \mathrm{mM}$ AMP-PCP to a final volume of 50-60 $\mu \mathrm{L}$. For depleting ATP, eluted spliceosomes were incubated with $4.0 \mu \mathrm{L}$ recombinant hexokinase $(1 \mathrm{unit} / \mu \mathrm{L})$ and $2 \mathrm{mM}$ glucose for $10 \mathrm{~min}$ at $23^{\circ} \mathrm{C}$ before reconstitution. Samples were incubated for $45 \mathrm{~min}$ at $23^{\circ} \mathrm{C}$. When required, increasing concentrations of $\mathrm{KCl}$ were added to the samples which where then placed on ice and immediately subjected to real-time dcFCCS measurements.

\section{Labeling and purification of spliceosomes}

pre-mRNA was labeled as described below. Proteins were genetically modified by fusion to enhanced green fluorescent protein (EGFP). The different $\mathrm{B}^{\text {act } \Delta \operatorname{Prp} 2}$ complexes were assembled in vitro using heat-inactivated splicing extracts from yeast strains that were temperature-sensitive in the ATPase Prp2 (Yean and Lin 1991) and which stably expressed the protein of interest as an EGFP fusion protein (for details, see Supplemental Materials and Methods). The purified, doubly labeled $\mathrm{B}^{\text {act } \Delta \operatorname{Prp} 2}$ spliceosomes were then complemented with recombinant Prp2, Spp2, and ATP, and the weakening or strengthening of the binding of the EGFPlabeled protein to the spliceosome was measured by dcFCCS. Recombinant Spp2 was always added together with Prp2, as our purified $B^{\text {act } \Delta \text { Prp2 }}$ complexes lack Spp2 (Warkocki et al. 2009). Recombinant Cwc25 was chemically labeled with Atto488 as described in the Supplemental Materials and Methods.

\section{Labeling of pre-mRNAs with a fluorescent dye}

Guanosine-5'-O-monophosphorothioate (5'-GMPS) can be incorporated as the first nucleotide by T7 RNA polymerase in vitro. 5 '-GMPS-containing mature actin pre-mRNA was prepared by in vitro transcription of Acc65I digested pUC18-Actin-wt plasmid DNA with T7 RNA polymerase (40 mM Tris- $\mathrm{HCl}, \mathrm{pH} 8.0,30 \mathrm{mM}$ $\mathrm{MgCI}_{2}, 10 \mathrm{mM}$ DTT, $2 \mathrm{mM}$ spermidine, $0.1 \mathrm{U}$ yeast inorganic pyrophosphatase (NEB), $0.5 \mathrm{U}$ RNasin (Promega), $4 \mathrm{mM}$ ATP, $4 \mathrm{mM}$ CTP, 4 mM UTP, 1 mM GTP, 10 mM 5' -GMPS (Biolog); $37^{\circ} \mathrm{C}, 3 \mathrm{~h}$ ). Transcripts were purified by electrophoresis through $5 \%$ polyacrylamide, $8 \mathrm{M}$ urea gels and passively eluted into $0.5 \mathrm{M} \mathrm{NaOAc}$, pH 5.3, 1 mM EDTA, pH 8.0, 2.5\% phenol-chloroform-isoamyl alcohol.

To link the 5'-GMPS-modified pre-mRNA covalently to the fluorescent dye Atto647N, Atto647N-maleimide was incubated with the pre-mRNA in the presence of $100 \mathrm{mM} \mathrm{NaPO}_{4}$ ( $\mathrm{pH} 7.2$ ) at RT for $4 \mathrm{~h}$. The Atto647N-labeled pre-mRNA was prepurified by $4 \times$ ethanol precipitation and several washing steps to remove unreacted dye, resulting in nearly $100 \%$ labeled pre-mRNA. The dye:RNA stoichiometry was calculated according to the manufacturer's protocol (Molecular Probes).

\section{Dual-color FCCS setup}

The dcFCCS setup (MicroTime 200, PicoQuant GmbH) is based on an inverse epifluorescence microscope (IX-71, Olympus Europa). The system is equipped with two identical pulsed 470-nm diode lasers (LDH-P-C-470 B, PicoQuant GmbH) and two identical pulsed 635-nm diode lasers (LDH-P-635, PicoQuant GmbH) with linear polarization and a pulse duration of 50 psec (FWHM). The lasers are pulsed alternately with an overall repetition rate of 40 $\mathrm{MHz}$ (PIE mode) corresponding to a delay between pulses of 25 nsec (PDL 828 "Sepia II," PicoQuant GmbH). The light is focused by the microscope's objective (UPLSAPO $60 \times \mathrm{x}$ W, 1.2 N.A., Olympus Europa). Fluorescence is collected by the same objective (epifluorescence mode), passed through the dichroic mirror, and focused by a tube lens through a single circular aperture (diameter $150 \mu \mathrm{m})$. After the pinhole, the light is recollimated, split by a polarizing beam-splitter cube (Ealing Catalogue) and two dichroic mirrors (640 dcxr, Chroma Technology), and focused onto two single-photon avalanche diodes for the red (two SPCM-AQR-13, Perkin Elmer) and two for the green emission (PDM 50-C, Micro Photon Devices), respectively. This kind of excitation/emission scheme yields maximum information on fluorescence anisotropy and spectrum, although we subsequently use only the spectral information. Emission bandpass filters HC692/40 and HC520/35 (Semrock), positioned directly in front of each detector, are used for blocking scattered light. Time-correlated single-photon counting electronics (HydraHarp 400, PicoQuant $\mathrm{GmbH}$ ) independently record the detected photons of all detectors with an absolute temporal resolution of $4 \mathrm{psec}$ on a common time frame.

To avoid artefacts due to evaporation-induced convection or unspecific binding to the cover slide during our dcFCCS measurements, cover slides were coated with Sigmacote (SigmaAldrich) according to the manufacturer's instructions, and spliceosomal samples were hermetically sealed between two coated cover glasses using a silicone spacer (Grace Bio-Labs).

\section{SUPPLEMENTAL MATERIAL}

Supplemental material is available for this article.

\section{ACKNOWLEDGMENTS}

We thank Elke Penka, Thomas Conrad, and Wiebke BehrensKranz for excellent technical assistance. We thank Cindy Will for constructive comments. This work was supported by a grant from the Deutsche Forschungsgemeinschaft SFB 860 to R.L. and J.E.

Received March 19, 2012; accepted March 21, 2012.

\section{REFERENCES}

Arenas JE, Abelson JN. 1997. Prp43: An RNA helicase-like factor involved in spliceosome disassembly. Proc Natl Acad Sci 94: 11798-11802. 
Bartels C, Klatt C, Lührmann R, Fabrizio P. 2002. The ribosomal translocase homologue Snu114p is involved in unwinding U4/U6 RNA during activation of the spliceosome. EMBO Rep 3: 875-880.

Chang KJ, Chen HC, Cheng SC. 2009. Ntc90 is required for recruiting first step factor Yju2 but not for spliceosome activation. RNA 15: 1729-1739.

Chiu YF, Liu YC, Chiang TW, Yeh TC, Tseng CK, Wu NY, Cheng SC. 2009. Cwc25 is a novel splicing factor required after Prp2 and Yju2 to facilitate the first catalytic reaction. Mol Cell Biol 29: 5671-5678.

Dziembowski A, Ventura AP, Rutz B, Caspary F, Faux C, Halgand F, Laprevote O, Seraphin B. 2004. Proteomic analysis identifies a new complex required for nuclear pre-mRNA retention and splicing. EMBO J 23: 4847-4856.

Fabrizio P, Dannenberg J, Dube P, Kastner B, Stark H, Urlaub H, Lührmann R. 2009. The evolutionarily conserved core design of the catalytic activation step of the yeast spliceosome. Mol Cell 36: 593-608.

Földes-Papp Z, Rigler R. 2001. Quantitative two-color fluorescence cross-correlation spectroscopy in the analysis of polymerase chain reaction. Biol Chem 382: 473-478.

Giaever G, Chu AM, Ni L, Connelly C, Riles L, Veronneau S, Dow S, Lucau-Danila A, Anderson K, Andre B, et al. 2002. Functional profiling of the Saccharomyces cerevisiae genome. Nature 418: 387391.

Goldfeder MB, Oliveira CC. 2008. Cwc24p, a novel Saccharomyces cerevisiae nuclear ring finger protein, affects pre-snoRNA U3 splicing. J Biol Chem 283: 2644-2653.

Gozani O, Potashkin J, Reed R. 1998. A potential role for U2AF-SAP 155 interactions in recruiting U2 snRNP to the branch site. Mol Cell Biol 18: 4752-4760.

Hilliker AK, Mefford MA, Staley JP. 2007. U2 toggles iteratively between the stem IIa and stem IIc conformations to promote premRNA splicing. Genes Dev 21: 821-834.

Hogg R, McGrail JC, O'Keefe RT. 2010. The function of the NineTeen Complex (NTC) in regulating spliceosome conformations and fidelity during pre-mRNA splicing. Biochem Soc Trans 38: 11101115.

Horowitz DS. 2011. The mechanism of the second step of pre-mRNA splicing. WIRES RNA doi: 10.1002/wrna.112.

James SA, Turner W, Schwer B. 2002. How Slu7 and Prp18 cooperate in the second step of yeast pre-mRNA splicing. RNA 8: 1068-1077.

Kettling U, Koltermann A, Schwille P, Eigen M. 1998. Real-time enzyme kinetics monitored by dual-color fluorescence crosscorrelation spectroscopy. Proc Natl Acad Sci 95: 1416-1420.

Kim SH, Lin RJ. 1996. Spliceosome activation by PRP2 ATPase prior to the first transesterification reaction of pre-mRNA splicing. Mol Cell Biol 16: 6810-6819.

Kim SH, Smith J, Claude A, Lin RJ. 1992. The purified yeast premRNA splicing factor PRP2 is an RNA-dependent NTPase. EMBO J 11: 2319-2326.

King DS, Beggs JD. 1990. Interactions of PRP2 protein with premRNA splicing complexes in Saccharomyces cerevisiae. Nucleic Acids Res 18: 6559-6564.

Lardelli RM, Thompson JX, Yates JR III, Stevens SW. 2010. Release of SF3 from the intron branchpoint activates the first step of premRNA splicing. RNA 16: 516-528.

Liu YC, Chen HC, Wu NY, Cheng SC. 2007. A novel splicing factor, Yju2, is associated with NTC and acts after Prp2 in promoting the first catalytic reaction of pre-mRNA splicing. Mol Cell Biol 27: $5403-5413$
McPheeters DS, Muhlenkamp P. 2003. Spatial organization of protein-RNA interactions in the branch site- $3^{\prime}$ splice site region during pre-mRNA splicing in yeast. Mol Cell Biol 23: 4174-4186.

Nilsen TW. 1998. RNA-RNA interactions in nuclear pre-mRNA splicing. In RNA structure and function (ed. M GrundbergManago, RW Simons), pp. 279-307. Cold Spring Harbor Laboratory Press, Cold Spring Harbor, NY.

Ohi MD, Link AJ, Ren L, Jennings JL, McDonald WH, Gould KL. 2002. Proteomics analysis reveals stable multiprotein complexes in both fission and budding yeasts containing Myb-related Cdc5p/ Cef1p, novel pre-mRNA splicing factors, and snRNAs. Mol Cell Biol 22: 2011-2024.

Ohrt T, Staroske W, Mutze J, Crell K, Landthaler M, Schwille P. 2011. Fluorescence cross-correlation spectroscopy reveals mechanistic insights into the effect of $2^{\prime}$-O-methyl modified siRNAs in living cells. Biophys J 100: 2981-2990.

Perriman RJ, Ares M Jr. 2007. Rearrangement of competing U2 RNA helices within the spliceosome promotes multiple steps in splicing. Genes Dev 21: 811-820.

Puig O, Caspary F, Rigaut G, Rutz B, Bouveret E, Bragado-Nilsson E, Wilm M, Séraphin B. 2001. The tandem affinity purification (TAP) method: A general procedure of protein complex purification. Methods 24: 218-229.

Roy J, Kim K, Maddock JR, Anthony JG, Woolford JL Jr. 1995. The final stages of spliceosome maturation require Spp2p that can interact with the DEAH box protein Prp2p and promote step 1 of splicing. RNA 1: 375-390.

Schwer B, Gross CH. 1998. Prp22, a DExH-box RNA helicase, plays two distinct roles in yeast pre-mRNA splicing. EMBO J 17: 2086-2094.

Silverman EJ, Maeda A, Wei J, Smith P, Beggs JD, Lin RJ. 2004. Interaction between a G-patch protein and a spliceosomal DEXD/ H-box ATPase that is critical for splicing. Mol Cell Biol 24: 1010110110.

Small EC, Leggett SR, Winans AA, Staley JP. 2006. The EF-G-like GTPase Snu114p regulates spliceosome dynamics mediated by Brr2p, a DExD/H box ATPase. Mol Cell 23: 389-399.

Staley JP, Guthrie C. 1998. Mechanical devices of the spliceosome: Motors, clocks, springs, and things. Cell 92: 315-326.

Teigelkamp S, McGarvey M, Plumpton M, Beggs JD. 1994. The splicing factor PRP2, a putative RNA helicase, interacts directly with pre-mRNA. EMBO J 13: 888-897.

Tsai WY, Chow YT, Chen HR, Huang KT, Hong RI, Jan SP, Kuo NY, Tsao TY, Chen CH, Cheng SC. 1999. Ceflp is a component of the Prp19p-associated complex and essential for pre-mRNA splicing. J Biol Chem 274: 9455-9462.

Wahl MC, Will CL, Lührmann R. 2009. The spliceosome: Design principles of a dynamic RNP machine. Cell 136: 701-718.

Warkocki Z, Odenwälder P, Schmitzová J, Platzmann F, Stark H, Urlaub H, Ficner R, Fabrizio P, Lührmann R. 2009. Reconstitution of both steps of Saccharomyces cerevisiae splicing with purified spliceosomal components. Nat Struct Mol Biol 16: 1237-1243.

Will CL, Lührmann R. 2011. Spliceosome structure and function. In RNA World (ed. RF Gesteland et al.), pp. 181-203. Cold Spring Harbor Laboratory Press, Cold Spring Harbor, NY.

Winzeler EA, Shoemaker DD, Astromoff A, Liang H, Anderson K, Andre B, Bangham R, Benito R, Boeke JD, Bussey H, et al. 1999. Functional characterization of the $S$. cerevisiae genome by gene deletion and parallel analysis. Science 285: 901-906.

Yean SL, Lin RJ. 1991. U4 small nuclear RNA dissociates from a yeast spliceosome and does not participate in the subsequent splicing reaction. Mol Cell Biol 11: 5571-5577. 

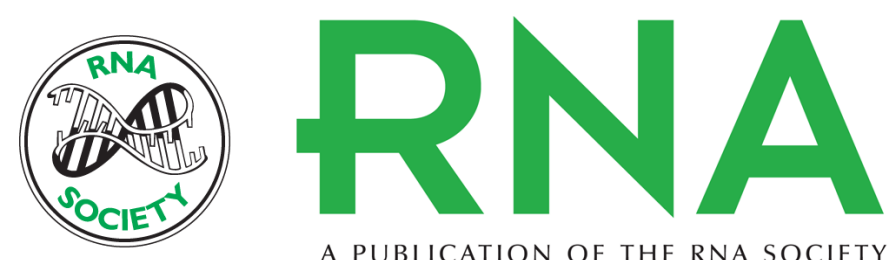

A PUBLICATION OF THE RNA SOCIETY

\section{Prp2-mediated protein rearrangements at the catalytic core of the spliceosome as revealed by dcFCCS}

Thomas Ohrt, Mira Prior, Julia Dannenberg, et al.

RNA 2012 18: 1244-1256 originally published online April 25, 2012

Access the most recent version at doi:10.1261/rna.033316.112

Supplemental
Material http://rnajournal.cshlp.org/content/suppl/2012/04/09/rna.033316.112.DC1

References This article cites 35 articles, 21 of which can be accessed free at: http://rnajournal.cshlp.org/content/18/6/1244.full.html\#ref-list-1

\section{License}

Email Alerting Receive free email alerts when new articles cite this article - sign up in the box at the Service top right corner of the article or click here.

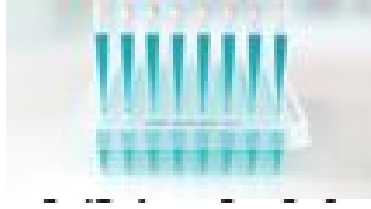

Providing Precise Solutions for your research.

To subscribe to RNA go to:

http://rnajournal.cshlp.org/subscriptions 